Crop Breeding and Applied Biotechnology 15: 272-277, 2015

Brazilian Society of Plant Breeding. Printed in Brazil

\title{
ARTICLE
}

http://dx.doi.org/10.1590/1984-70332015v15n4a45

\section{Genetic and cytogenetic structure of wild lemon grass (Elionurus muticus) populations}

Thanise Nogueira Füller ${ }^{1 *}$, Divanilde Guerra ${ }^{1}$, Maria Teresa Schifino Wittmann ${ }^{1}$, Carolina Tessele ${ }^{1}$, Ingrid Bergman Inchausti de Barros ${ }^{1}$ and José Fernandes Barbosa Neto ${ }^{1}$

Received 30 April 2015

Accepted 19 Jun 2015

\begin{abstract}
Elionurus muticus is a native aromatic grass from the Pampa biome that produces an essential oil that is rich in citral. Despite the importance of citral, few studies have examined this species. The aims of this work were to evaluate the genetic structure and to characterize cytogenetically natural populations collected from Brazil. Genetic characterization was performed using AFLP markers, and cytogenetics assessed the chromosome number, karyotype and meiosis. The studied populations had genetic variability, especially within populations, indicating the possibility of selecting plants with relevant characters. High variability also suggests the preferential occurrence of outcrossing in natural populations. Regular meiosis was observed in the cytogenetic analysis with chromosome number $2 n=20$. The karyotype of the species is presented for the first time, with the karyotype formula 3 sm $+4 a+1$ sa ${ }^{S A T}$.
\end{abstract}

Key words: Satellite chromosome, Karyotype, Genetic diversity, Euclidean distance.

\section{INTRODUCTION}

The demand for natural products is growing, and essential oils are among the most popular natural products. The species Elionurus muticus has great potential in producing the main essential oils economically important for grass. This species is highlighted by the presence of an essential oil rich in citral, which is one of the most commercialized essential oil compounds (Castro and Ramos 2003).

E. muticus, popularly known as lemon grass, belongs to the Poaceae family and is native to the Pampa biome, comprising Brazil, Argentina and Uruguay, where it is present in abundance (Welker and Longhi-Wagner 2007). Thus, this grass demands little or no-demand management, which makes it a potential resource of an essential oil (Castro and Ramos 2003). Despite the presence of essential oils and the growing demand, few studies have been conducted, and knowledge of the biology and agronomy of this species is reduced. However, recent analyses have indicated the presence of genetic and chemical variability in populations from southern Brazil (Füller et al. 2014), Argentina (Cacciabua et al. 2005) and Africa (Mevy et al. 2002, Silou et al. 2006).
Currently, many aromatic plants are collected from wild populations; consequently, demand for wild plants can affect species occurrence and distribution. Therefore, the development of cultivation techniques is required to obtain high-quality products without jeopardizing natural populations (Lyke 2001, Small et al. 2011). Thus, characterization and evaluation, both in terms of qualitative and quantitative traits, are essential and should be priorities considering genetic resource management strategies (Neitzke et al. 2010). It is necessary great efforts to increase knowledge about $E$. muticus to determine the best way to explore the potential of this species. Hence, the aims of this study were to evaluate the genetic structure of natural E. muticus populations and to characterize the specie cytogenetically.

\section{MATERIAL AND METHODS}

\section{Plant material}

Natural populations of E. muticus were collected from Rio Grande do Sul, Brazil. The populations were Águas Claras (lat $26^{\circ} 29^{\prime} \mathrm{S}$, long $49^{\circ} 4^{\prime} \mathrm{W}$ ), Fontoura Xavier (lat $28^{\circ} 53^{\prime} \mathrm{S}$, long $52^{\circ} 24^{\prime} \mathrm{W}$ ), São Borja (lat $28^{\circ} 47^{\prime} \mathrm{S}$, long $56^{\circ} 05^{\prime} \mathrm{W}$ ), São Francisco de Paula (lat $28^{\circ} 47^{\prime}$, long $56^{\circ}$

${ }^{1}$ Faculdade de Agronomia, Universidade Federal do Rio Grande do Sul, Av. Bento Gonçalves, 7712, Caixa Postal 776, 91501-970, Porto Alegre, Brazil. * E-mail: thanisenf@yahoo.com.br. 
$05^{\prime} \mathrm{W}$ ), Uruguaiana (lat $29^{\circ} 29^{\prime} \mathrm{S}$, long $56^{\circ} 45^{\prime} \mathrm{W}$ ) and the two mountains in Porto Alegre city: Morro Santana (lat $30^{\circ} 03^{\prime} \mathrm{S}$, long $51^{\circ} 07^{\prime} \mathrm{W}$ ) and Morro São Pedro (lat $29^{\circ}$ $20^{\prime} \mathrm{S}$, long $\left.50^{\circ} 31^{\prime} \mathrm{W}\right)$. The collected herbarium material was assembled and cataloged in the Herbário ICN of the Departamento de Botânica/UFRGS (Águas Claras- ICN 152283, Morro Santana - ICN 152281, São Borja - ICN 152282, São Francisco de Paula - ICN 152279 and Uruguaiana - ICN 152280). The harvested plants were transplanted to 5 liters pots containing substrate and kept outdoors at the Departamento de Horticultura e Silvicultura of Faculdade de Agronomia/UFRGS.

\section{Molecular analysis}

DNA was extracted from the leaves of ten individuals from each population, except for the São Borja population, from which 19 individuals were evaluated. Extractions were performed following the method described by Harberer (1998). The evaluated molecular markers were AFLP, and the amplification reactions followed a method adapted from Vos et al. (1995). Genomic DNA (250 ng) was digested with the restriction enzymes $M s e I$ and $P s t I$. Specific adapters to the restriction sites were added to the digested DNA. The PCR reaction for pre-amplification consisted of $10 \mathrm{ng}$ of ligated DNA, $37.5 \mathrm{ng}$ of each initializer with an added nucleotide sequence (MseI $+\mathrm{C}$ and $P s t I+\mathrm{A}), 0.8 \mathrm{mM}$ dNTP, $1 \times$ buffer and one unit of Taq DNA polymerase. Pre-amplification was performed in 20 cycles under the conditions of $94{ }^{\circ} \mathrm{C}$ for $30 \mathrm{sec}, 56{ }^{\circ} \mathrm{C}$ for $1 \mathrm{~min}$ and $72^{\circ} \mathrm{C}$ for $1 \mathrm{~min}$. The PCR reaction for amplification contained $20 \mathrm{ng}$ of pre-amplified DNA, $30 \mathrm{ng}$ of both $\mathrm{MseI}$ and PstI primers plus three nucleotides, $1.5 \mathrm{mM} \mathrm{MgCl}_{2}, 0.8 \mathrm{mM}$ dNTP, $1 \times$ buffer and one unit of Taq DNA polymerase. Selective amplification was carried out with touchdown a PCR program with cycles of $94{ }^{\circ} \mathrm{C}$ for $60 \mathrm{~s}, 65^{\circ} \mathrm{C}$ for $60 \mathrm{sec}$ and $72{ }^{\circ} \mathrm{C}$ for $90 \mathrm{sec}$. The pairing temperature started at $65^{\circ} \mathrm{C}$ and was decreased by $1{ }^{\circ} \mathrm{C}$ until $56^{\circ} \mathrm{C}$, which was maintained for 23 cycles. The amplification reactions were performed with the primer sequences P_ACT + M_CTA, P_AAC + M_CAC, P_ACT $+\mathrm{M} \_\mathrm{CCG}$ and $\mathrm{P} \_\mathrm{AAA}+\mathrm{M}$ _CCG. The amplified fragments were separated by electrophoresis in a $5 \%$ denaturing polyacrylamide gel at $85 \mathrm{~W}$ for approximately 3 hours. A 100-bp DNA Ladder-marker was used as molecular weight standard. The gels were stained with silver nitrate. A visual analysis of the fragments was performed on a fluorescent light table by two readers. The size of the fragments was estimated by comparing the migration of molecular weight marker fragments (DNA ladder), as determined from the application point of each gel.

The individuals were genotyped based on the presence/ absence of bands, permitting the observance of recessive allele frequencies assuming Hardy-Weinberg equilibrium. From the allele frequencies, an analysis of similarity was obtained based on Euclidean distance. The clustering was performed by the UPGMA method using the R program. The partition of the variability among and within populations was performed by a molecular analysis of variance (AMOVA) also using the R program. Wright's Fst value (1943) was calculated to verify the population genetic structure. This analysis followed the model of Lynch and Milligan (1994). The genetic variability for each population was estimated according to the proportion of polymorphic loci (P: 0.95), the observed (Ho) and expected $(\mathrm{He})$ average heterozygosity per locus, and the inbreeding coefficient. This analysis and Wright's Fst were performed using the UPGMA program (Miller 1997).

\section{Cytogenetic analysis}

The cytogenetic characterization of the chromosome number, meiosis and karyotype were all performed with the São Borja population, and an analysis of pollen fertility was performed for Morro Santana, São Borja and Uruguaiana. The somatic chromosome number was determined in the root tip cells of ten individuals. The collected roots were pretreated with a saturated solution of paradichlorobenzene (PDB) for $24 \mathrm{~h}$ at $4{ }^{\circ} \mathrm{C}$. After the root tips were fixed in a solution with $60 \%$ ethanol, $30 \%$ chloroform and $10 \%$ acetic acid for $24 \mathrm{~h}$ at room temperature. The roots were then stored in $70 \%$ alcohol at $-20{ }^{\circ} \mathrm{C}$. The slides were prepared via the hydrolysis of the root tips in an $1 \mathrm{~N} \mathrm{HCl}$ in water bath at $60^{\circ} \mathrm{C}$ for $10 \mathrm{~min}$, after which the root tips were stained with Feulgen for approximately $3 \mathrm{~h}$. Then, an enzyme treatment was carried out with $2 \%$ pectinase for approximately $20 \mathrm{~min}$. The root tips were then macerated in $2 \%$ propionic carmine. The slide was covered with a cover slip and sealed with mourning 3: 1 (pitch: wax). For each individual, ten cells were analyzed with a good scattering of chromosomes and equivalent contraction stages. All of the analyses were carried out under an optical Nikon microscope with a traditional photography system.

Karyotype analyses were carried out as follows: the number of chromosomes; the length of the long (L) and short $(\mathrm{S})$ arms; the total length $(\mathrm{TL}=\mathrm{L}+\mathrm{S})$; the centromeric index $\left(\mathrm{CI}=\mathrm{S} . \mathrm{TL}^{-1} \cdot 100\right)$; the mean value of the total length of the whole chromosome (TLG); the sum of the total length (RTL); and the ratio between the length of the longest pair/and the shortest pair (R). The centromere position was expressed as arm ratio values ( $\mathrm{r}=\mathrm{long} / \mathrm{short}$ arm). The chromosomes were classified based on their centromere position, considered metacentric (m) (where CI was greater 
than 0.40 ), submetacentric (sm) (between 0.36 and 0.40 ) acrocentric (a) ( 0.25 to 0.35 ) and subacrocentric (s) (CI less than 0.25$)$. The results were represented in an idiogram. The degree of symmetry of the karyotype was calculated according to Stebbins (1971).

The meiotic behavior was observed in young inflorescences. The inflorescences were collected and immediately fixed in a solution of absolute ethanol: acetic acid (3:1) for $24 \mathrm{~h}$ at room temperature and were then stored in $70 \%$ ethanol in the freezer for further analysis. To prepare the slides, the anthers were separated using tweezers and a histological needle. After the anthers were crushed, they were stained with $2 \%$ propionic carmine and pressed lightly with a glass rod. The slides were analyzed using an optical microscope. At least ten cells with good chromosome spreading and with chromosomes in equivalent degree of contraction were analyzed per plant. All available cells were analyzed and all stages from meiosis I, where bivalent associations occurs, were observed; however, for meiosis II, it was not possible to observe metaphase or anaphase.

\section{RESULTS AND DISCUSSION}

AFLP variation in band profiles of the 85 genotypes resulted in 133 consistent markers, all polymorphic. The dendrogram showed that, in general, the markers grouped the populations according to geographic location (Figure 1). The cluster among the populations Morro Santana and Morro São Pedro, as well as the cluster between São Borja and Uruguaiana, reflected their geographical origin. Morro Santana and Morro São Pedro are both mountains in the same city and have similar characteristics, such as high altitudes. The Uruguaiana and São Borja cluster also reflects this geographical similarity, as both cities are located on the border with Argentina, separated by approximately 160

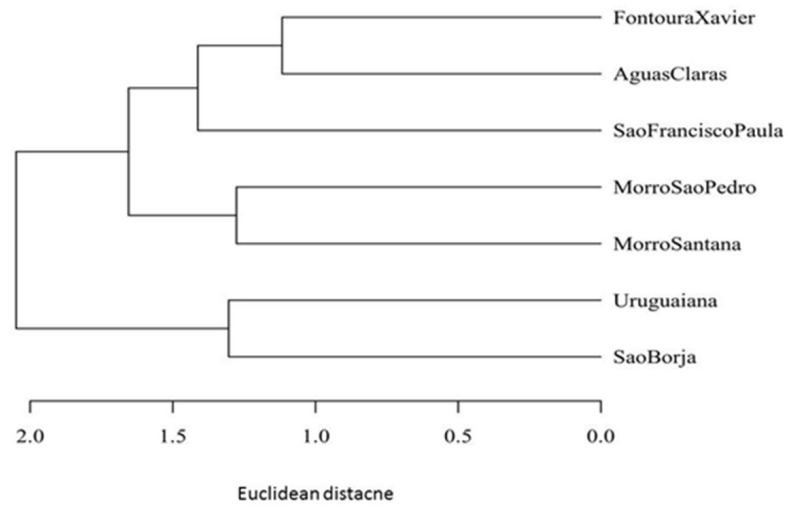

Figure 1. Cluster of Elionurus muticus natural populations that were obtained by AFLP molecular markers, based on Euclidean distance. $\mathrm{km}$ from each other. However, when considering cluster of Fontoura Xavier, Águas Claras and São Francisco de Paula, it was not possible to assign a geographical origin similarity. The group that was formed by populations of Uruguaiana and São Borja was further related to other populations, which also reflects the geographical distance of these populations relative to the other populations. The results indicate that differences in ecosystems may reflect the molecular analysis and that the variation may be attributed to differences in the number of alleles per locus and their distribution within the population. The relationship between genetic variability and geographic distribution has been observed in various aromatic plants (Füller et al. 2010, Zhang et al. 2013).

The estimated percentage of polymorphic loci revealed that the populations São Borja, Uruguaiana and Fontoura Xavier had more genetic variability compared to that of the other populations (Table 1). The populations Fontoura Xavier and São Borja had larger samples, which may be reflected in the more-pronounced variability.

The observed heterozygosity ranged from 0.10 to 0.29 between populations, with an overall heterozygosity of 0.36 . The values that were reported for observed heterozygosity were similar to the expected heterozygosity values, indicating a tendency for cross-pollination (Table 1). The inbreeding coefficient showed that, overall, there is reduced homozygosity, with values less than 0.1 , again suggesting cross-pollination. Águas Claras and São Francisco de Paula populations had the highest inbreeding coefficient $(0.1)$, indicating that these populations present a higher frequency of homozygotes compared with other populations. Wright Fst value was 0.28 , indicating a differentiation between the populations (Wright 1943). This differentiation was expected, as it is a reflection of the geographic distance between populations, preventing gene flow between them. The analysis of molecular variance revealed greater intrapopulational $(76 \%)$ than interpopulational $(24 \%)$ variability.

Table 1. Proportion of polymorphic loci (P), observed (Ho) and expected (He) heterozygosity and inbreeding coefficient (f) of seven Elionurus muticus populations

\begin{tabular}{lccccc}
\hline Population & $\mathbf{N}^{*}$ & $\mathbf{P}(95 \%)$ & Ho & He & $\mathbf{f}$ \\
\hline Águas Claras & 10 & 24.13 & 0.10 & 0.11 & 0.10 \\
Fontoura Xavier & 17 & 72.41 & 0.27 & 0.28 & 0.06 \\
Morro Santana & 10 & 51.72 & 0.19 & 0.20 & 0.05 \\
Morro São Pedro & 10 & 55.17 & 0.25 & 0.26 & 0.04 \\
São Borja & 18 & 82.75 & 0.29 & 0.30 & 0.04 \\
São Francisco de Paula & 10 & 51.72 & 0.20 & 0.22 & 0.10 \\
Uruguaiana & 10 & 72.41 & 0.26 & 0.28 & 0.07 \\
Total & 85 & 89.65 & 0.36 & 0.36 & 0.00 \\
\hline
\end{tabular}

* number of individuals. 
Table 2. Elionurus muticus karyotype data: mean length and centromeric index (CI) of each pair of chromosomes and the total length of the haploid complement (TCL)

\begin{tabular}{lcccccccccc}
\hline Chromosome & $\mathbf{1}$ & $\mathbf{2}$ & $\mathbf{3}$ & $\mathbf{4}$ & $\mathbf{5}$ & $\mathbf{6}$ & $\mathbf{7}$ & $\mathbf{8}$ & $\mathbf{9}$ & $\mathbf{1 0}$ \\
\hline Total length $(\mu \mathrm{m})$ & 6.25 & 5.64 & 5.50 & 5.12 & 5.00 & 4.55 & 4.54 & 4.09 & 3.86 & 3.71 \\
CI & 0.38 & 0.40 & 0.39 & 0.39 & 0.38 & 0.44 & 0.20 & 0.30 & 0.35 & 0.33 \\
\hline
\end{tabular}

TCL $(\mu \mathrm{m})$ 48.3

The evaluated individuals had 10 pairs of chromosomes each $(2 \mathrm{n}=20)$, all homogeneous. In general, grasses have a greater diversity of chromosome number, and their basic chromosome number ranges from $\mathrm{x}=2-18$. $E$. muticus belongs to the subfamily Panicoideae, which has a basic number $x=9$ and 10 (Hilu 2004). The number of chromosomes that were found in this study is consistent with previous studies of other species of the genus Elionurus, which also reported the presence of ten pairs of chromosomes (Brown 1951, Gould and Soderstrom 1967). The exception is an African species, E. argenteus, which presents basic number $\mathrm{x}=5$ (Celarier 1957).

The E. muticus chromosomes measured between 3 and 6 microns and were considered relatively large compared to those of other plants (Table 2). The size of the chromosomes shows a wide variation between species, including plants with very small chromosomes, such as Leucaena (approximately 1 micron) (Schifino-Wittmann 2004), Jatropha genus (1 to 2 microns) (Dahmer et al. 2009) and Maytenus species (approximately 0.5 microns) (Lunardi et al. 2004); with average-sized chromosomes, such as Trifolium argentinense species (1.6 to 2.8 microns) (Conterato et al. 2010) and the Elytrigia genus (ca 2 microns) (Mao et al. 2010); and with large chromosomes, such as Lathyrus genus (4-7 microns) (Klamt and Schifino-Wittmann 2000) and the species Cipura paludosa (approximately 9.5 microns) (Alves et al. 2011).

The E. muticus karyotype showed a predominance of submetacentric chromosomes, including four pairs of chromosomes (1,3,4 and 5), and also presented three pairs of acrocentric chromosomes ( 6,8 and 9$)$, a subacrocentric

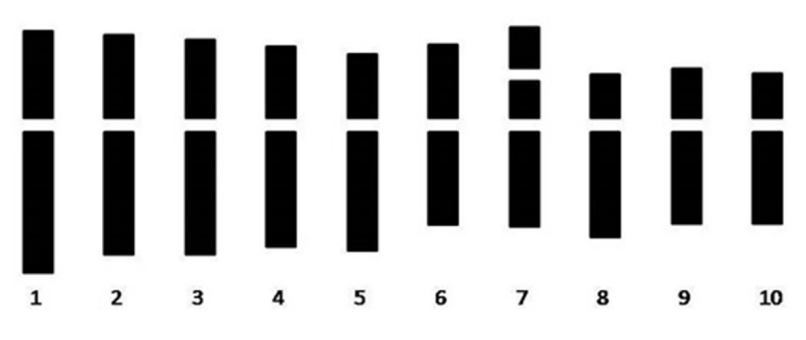

Figure 2. Idiogram of the chromosome complement of Elionurus muticus. The scale bar corresponds to $10 \mu \mathrm{m}$. chromosome (7) and two metacentric chromosomes ( 2 and 6) (Figure 2). The karyotype analysis also permitted the observation of the presence of a satellite chromosome pair (7). The karyotype formula was determined as $2 \mathrm{~m}+3 \mathrm{sm}$ $+4 \mathrm{a}+1 \mathrm{sa}^{\mathrm{SAT}}$ and $\mathrm{TCL}=48.3$ microns. The chromosomal location of the satellites is always constant in individuals, except in the case of structural alterations, and thus can be used as morphological chromosome markers. In general, there is a pair of chromosomes with satellites in diploid species (Klamt and Schifino-Wittmann 2000, Conterato et al. 2010, Alves et al. 2011).

The E. muticus karyotype could be classified as 2A type
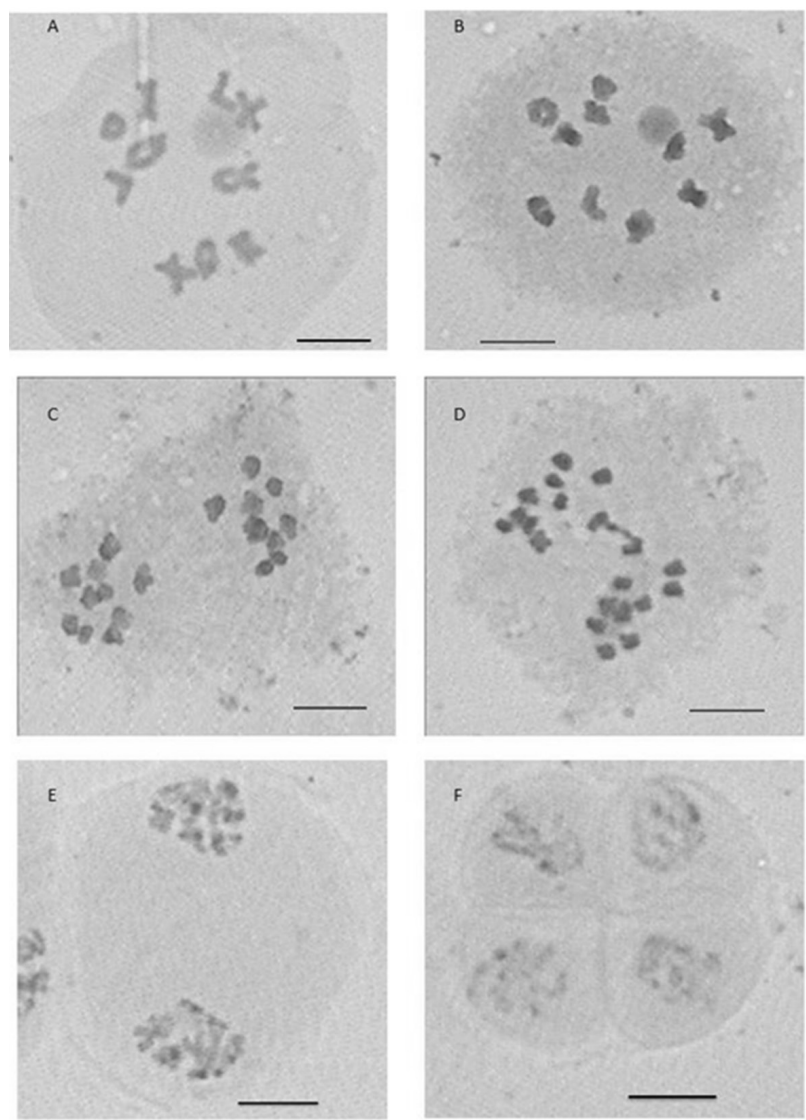

Figure 3. Elionurus muticus' cells in meiosis. (A-B) diakinesis cells, (c) cell in anaphase I, (D) cell bridged in anaphase I (E) cell in telophase I, and (F) tetrads. The scale bar corresponds to $10 \mu \mathrm{m}$. 
TN Füller et al.

Table 3. Analysis of the meiotic behavior of Elionurus muticus

\begin{tabular}{|c|c|c|c|c|}
\hline Individual & $\begin{array}{c}\text { Meiosis I } \\
\text { association diakinesis and metaphase I }\end{array}$ & Anaphase segregation and telophase I & Others Telophase II & Total cells \\
\hline SB02 & 10II (87) & $10-10(13)$ & - & 100 \\
\hline SB25 & $10 \mathrm{II}(42)$ & $10-10(31)$ & Normal (1) & 75 \\
\hline SB33 & $10 \mathrm{II}(17)$ & $10-10(24)$ & Normal (4) & 45 \\
\hline SB43 & $10 \mathrm{II}(84)$ & $10-10(53)(3) \mathrm{P}$ & - & 140 \\
\hline SB45 & $10 \mathrm{II}(43) 8 \mathrm{II}+2 \mathrm{I}(1)$ & $10-10(1)$ & - & 45 \\
\hline SB46 & $10 \mathrm{II}(33) 8 \mathrm{II}+2 \mathrm{I}(1)$ & $10-10(11)$ & - & 45 \\
\hline SB47 & 10II (49)8II + 2I (1) & $10-10(14)$ & Normal (3) & 66 \\
\hline
\end{tabular}

${ }^{1} \mathrm{I}=$ univalent; $\mathrm{II}=$ bivalent, $\mathrm{P}=$ cells with chromosomal bridges. In parentheses, the number of cells that were analyzed.

by the Stebbins (1971) karyotype symmetry index. According to Stebbins (1971), there is an evolutionary trend toward karyotype asymmetry. However, as there is no information on the karyotype of other species of Elionurus, due to the lack of comparison, we cannot assume this trend.

The large size of the chromosomes allowed an accurate view of chromosomal associations. All of the individuals showed $\mathrm{n}=10$ in diakinesis (Table 3, Figure 3) with no variation and agreed with the assessed somatic number $(2 \mathrm{n}$ $=20$ ). Every phase of the meiosis I was observed; however, for meiosis II, it was not possible to observe metaphase or anaphase. The cells that presented 10 bivalents or those that did not present chromosome bridges were considered normal chromosomes.

In general, E. muticus has a regular meiotic division. Bivalent associations were prevalent, appearing in all individuals. In the individuals SB45, SB46 and SB47, univalents were observed in some cells. The individual SB43 showed approximately $5 \%$ of the cells with chromosomal bridges (Figure 3). In natural populations, the occurrence of meiotic irregularities in general is not common, although there are exceptions, such as some species of the genus Scenecio (Lopes et al. 2002) and Onobrychis chorassanica (Ranjbar et al. 2010). The low frequency of meiotic abnormalities that was observed in E. muticus agrees with that observed in most natural populations of plant species (Fachinetto et al. 2008, Palma-Silva et al. 2008).

The results obtained contribute for germplasm characterization and for plant breeding, improving our understanding of the evolution of the genus.

\section{ACKNOWLEDGMENTS}

The authors acknowledge the Coordenação de Aperfeiçoamento de Pessoal de Ensino Superior (Capes) and the Conselho Nacional de Desenvolvimento Científico e Tecnológico (CNPq) for financial support and Dr. Fernanda Bered, Dr. Magnólia Silva, and Dr. Geraldo Soares for valuable suggestions.

\section{Estrutura genética e citogenética de populações naturais de capim-limão (Elionurus muticus)}

Resumo - Elionurus muticus é uma gramínea aromática nativa do bioma Pampa, que produz um óleo essencial rico em citral. Apesar da importância do citral, poucos estudos têm sido realizados para esta espécie. Os objetivos deste trabalho foram avaliar a estrutura genética e caracterizar citogenéticamente populações naturais de E. muticus do sul do Brasil. A caracterização genética foi realizada utilizando marcadores AFLP e a citogenética avaliou o número de cromossomos, cariótipo e meiose. As populações estudadas apresentaram variabilidade genética, especialmente dentro das populações, indicando a possibilidade de seleção de plantas com caracteres relevantes. A alta variabilidade também sugere a ocorrência preferencial de alogamia nas populações naturais. A meiose observada na análise citogenética foi regular, com número cromossômico $2 n=20$. O cariótipo da espécie é apresentado pela primeira vez, com a fórmula cariotípica $3 \mathrm{sm}+4 a+1 s a^{S A T}$.

Palavras-chave: Cromossomo satélite, cariótipo, diversidade genética, distância euclideana.

\section{REFERENCES}

Alves LIF, Lima SAA and Felix LP (2011) Chromosome characterization and variability in some Iridaceae from Northeastern Brazil. Genetics and Molecular Biology 34: 259-267.
Brown WV (1951) Chromosome numbers of some Texas grasses. Bulletin of the Torrey Botanical Club 78: 292-299.

Cacciabue M, Gallucci N, Cordero GP, Kolb N, Demo M and Sabini L (2005) Elionurus muticus from north of Argentina: evaluation of 
the antibacterial activity of three essential oil chemotypes. Biocell 29: $223-226$.

Castro LO and Ramos RLD (2003) Principais gramíneas produtoras de óleos essenciais: Cymbopogon citratus, capim-cidró, Cymbopogon martinii (Rox.) J.F. Watson, palma-rosa, Cymbopogon nardus (L.) Rendle, citronela, Elyonurus candidus (Trin.) Hack., capim-limão, Vetiveria zizanioides Nash, vetiver. Fepagro 11: 1-31.

Celarier RP (1957) Elionurus argenteus, a south african grass with five chromosome pairs. Bulletin of the Torrey Botanical Club 8: 157162.

Conterato IF, Schifino-Wittmann MT and Dall'Agnol M (2010) Seed dimorphism, chromosome number and karyotype of the amphicarpic species Trifolium argentinense Spreg. Genetic Resources and Crop Evolution 57: 727-731.

Dahmer N, Schifino-Wittmann MT and Dias LAS (2009) Chromosome numbers of Jatropha curcas L.: an important agrofuel plant. Crop Breeding and Applied Biotechnology 9: 386-389.

Fachinetto JM, Laughinghouse IV MHD, Silva ACF and Tedesco SB (2008) Variability of the chromosomal number and meiotic behavior in populations of Bidens pilosa from southern Brazil. Caryologia 61: $164-169$.

Füller TN, Tessele C, de Barros IBI and Barbosa Neto JF (2010) Phenotypical, phytochemical and molecular characterization of capimcarona [Elionurus muticus (Spreng.) Kuntze] populations. Brazilian Journal of Medicinal Plants 12: 261-268.

Füller TN, Bertrand C, Simon A, de Barros IBI and Barbosa Neto JF (2014) Elionurus muticus as an alternative source of citral from Pampa biome, Brazil. Journal of Oleo Science 63: 1109-1116.

Gould FW and Soderstrom TR (1967) Chromosome numbers of tropical American grasses. American Journal of Botany 54: 676-683.

Haberer G (1998) Mapping of the nucleolus organizer region on chromosome 4 in Arabidopsis thaliana. Molecular and General Genetics 250: 123-128.

Hilu KW (2004) Phylogenetics and chromosomal evolution in Poaceae (grasses). Australian Journal of Botany 52: 13-22.

Klamt A and Schifino-Witmann MT (2000) Karyotype morphology and evolution in Lathyrus species of southern Brazil. Genetics and Molecular Biology 23: 463-467.

Lopes MG, Wulff AF and Chifreda CC (2002) Chromosome contribution to Andean polyploid species of Senecio (Asteraceae), from Argentina. Caryologia 55: 27-35.

Lyke J (2001) Conservation status of Cimicifuga rubifolia, C. americana, and C. racemosa. Medicinal Plant Conservation (August issue): $22-24$.

Lynch M and Milligan BG (1994) Analysis of population genetic structure with RAPD markers. Molecular Ecology 3: 91-99.

Lunardi MPM, Schifino-Witmann MT and de Barros IBI (2004) Chromosome number variability in the South American medicinal plant Maytenus ilicifolia (Celastraceae). Cytologia 69: 439-445.

Mao PS, Huang Y, Wang X, Meng L, Mao P and Zhang G (2010) Cytological evaluation and karyotype analysis in plant germplasms of Elytrigia Desv. Agricultural Sciences in China 9: 1553-1560.

Mevy JP, Bessiere JM, Dherbomez M and Viano J (2002) Composition and some biological activities of the essential oils from an African pasture grass: Elionurus elegans Kunth. Journal of Agricultural and Food Chemistry 50: 4240-4243.

Miller MP (1997) Tools for population genetic analyses (TFGPA), version 1.3: a Windows program for the analysis of allozyme and molecular population genetic data. Computer software distributed by author.

Neitzke RS, Barbieri RL and de Carvalho FIF (2010) Dissimilaridade genética entre acessos de pimenta com potencial ornamental. Horticultura Brasileira 28: 47-53.

Palma-Silva C, Paggi GM, Kaltchuk-silva E, Bered F and BodaneseZanettini MH (2008) Meiotic behavior and pollen viability of wild populations of the neotropical species Vriesea gigantean (Bromeliaceae). Plant Species Biology 23: 217-221.

Ranjbar M, Karamian R and Hajmoradi F (2010) Chromosome number and meiotic behaviour of two populations of Onobrychis chorassanica Bunge ( $O$. sect. Hymenobrychis) in Iran. Journal of Cell and Molecular Research 2: 49-55.

Schifino-Wittmann MT (2004) Cytogenetics of the genus Leucaena Benth. Ciência Rural 34: 309-314.

Silou T, Loubaki L, Figueredo G and Chalchat JC (2006) Study of essential oil composition of Elionurus hensii Schum from Congo. Journal of Essential Oil Research 18: 518-520.

Small CJ, Chamberlain JL and Mathews DS (2011) Recovery of black cohosh (Actaea racemosa L.) following experimental harvests. The American Midland Naturalist 166: 339-348.

Stebbins GL (1971) Chromosomal evolution in higher plants. AddisonWesley, Melbourne, 1971p.

Vos P, Hogers R, Bleeker M, Reijans M, van de Lee T, Hornes M, Frijters A, Pot J, Peleman J and Kuiper M (1995) AFLP: a new technique for DNA fingerprinting. Nucleic Acids Research 3: 4407-4414.

Welker CAD and Longhi-Wagner HMA (2007) Família poaceae no morro santana, Rio Grande do Sul, Brasil. Revista Brasileira de Biociências 5: 53-92.

Wright S (1943) Isolation by distance. Genetics 28: 114-138.

Zhang JY, Zhang J, Yang WZ, Yu H and Jin H (2013) Morphological diversity of wild medicinal Paris L. from China and Vietnam. African Journal of Biotechnology 10: 16421-16428. 